\title{
A térbeli igazságosság nyomában
}

\author{
Edward W. Soja: Seeking spatial justice \\ (University of Minnesota Press, Minneapolis, USA, \\ 2010, 256 0.)
}

\author{
MÓRICZ ÁDÁM
}

Az elmúlt négy évtized során a geográfiában jelentős szemléletbeli változások következtek be. A „kritikai fordulatként” emlegetett fejlődés egyik első és legfontosabb munkája David Harvey: Social Justice and the City című műve (Harvey 1973) volt, amely a tér keletkezésének marxista megközelítésű magyarázatával tovább erősítette a földrajzi gondolkodás társadalomtudományi alapjait. Hasonló mérföldkőnek tekinthetö Henri Lefebvre: The Production of Space címü kötete (Lefebvre 1991) is, amely - jórészt szintén marxista szemlélettel - értelmezi a geográfia által használt alapfogalmakat (pl. tér, társadalmi tér), illetve bemutatja a tér társadalmi termelésének és átalakulásának folyamatát. A két műről - és a szerzők munkásságáról - mind a mai napig parázs viták folynak, ugyanakkor mindez hozzájárult a geográfia elméleti hátterének átalakulásához és a társadalomtudományokhoz való egyre erőteljesebb kapcsolódásához.

A fenti művek és a - széles értelemben vett - új elméleti alapokat kereső földrajz célja a társadalom és a tér fogalmának összekapcsolása. Minden esetben központi kérdés, hogy hogyan jelenik meg a térben a társadalom, illetve mi jellemzi a társadalom teret alakító és befolyásoló tevékenységét. Mivel a társadalmi anomáliák és feszültségek térben is értelmezhetők, ezért a geográfia számára releváns problémát jelentenek. A térhez való hozzájutás, a tér használata és a tér feletti uralom megszerzése a kritikai gondolkodás fontos elemévé vált, amely - ahogy Harvey művének címe is jelzi - hamar elvezetett a társadalomban uralkodó igazságossági viszonyok elemzéséhez.

Az igazságosság és - azon belül - a társadalmi igazságosság fogalmát sokan és sokféleképp magyarázzák. Rendszerint úgy elemzik térbeli vetületét, mint a társadalmi igazságosság térbeliségét vagy az igazságtalanság urbanizációját. A kiegyensúlyozatlan társadalmi viszonyok és az - elsősorban városi - terek közötti szoros kapcsolatot legkonkrétabban a térbeli igazságosság (spatial justice) fogalma fejezi ki.

Ezen új fogalom értelmezéséhez és az igazságossági viszonyok széles körü földrajzi elemzéséhez járul hozzá Edward W. Soja: Seeking Spatial Justice című műve, amely két éve látott napvilágot a Minnesotai Egyetem kiadásában. Az elméleti alapokat

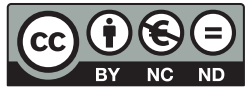


tisztázó és számos konkrét példával illusztráló mű célja az igazságosság kérdésének földrajzi vonatkozású elemzése, valamint a kiegyensúlyozatlan, konfliktusos térfolyamatok mögött megbúvó igazságtalan társadalmi viszonyok bemutatása.

A mű fontos szerepet tölt be a kritikai földrajz eddig publikált eredményeinek sorában, bár címadó fogalmát már korábban is leírták. A kilencvenes évek közepéig jobbára környezeti (environmental) vagy területi igazságosságként (territorial justice) emlegették (első említés: Davies 1968). Ez a munka még elég szüken értelmezte az igazságosság területiségét, úgy mint a közszolgáltatások egyenletes arányú és minőségű elosztásának lehetőségét. Harvey fő művében már jóval tágabb társadalmi értelmezést adott neki, és a társadalmi szempontból igazságtalan viszonyok keletkezésének folyamatára fektette a hangsúlyt. A kilencvenes évekre már egyre dinamikusabb és politikai színezetü lett ez a fajta igazságértelmezés, bár a térbeli igazságosság szemléletének konkrét alkalmazására csak elvétve került sor (pl. Pirie 1983). A térbeli igazságosság tartalmi megfogalmazására először Dikec tett kísérletet, kettébontva azt úgy, mint az igazságtalanság térbelisége és a térbeliség igazságtalansága (Dikec 2001). Ez a fogalom mögött rejtőző kettőség már jól tükrözi azt a dialektikus viszonyt, amelyről a térbeli igazságosság definiálása során Soja is beszél.

A szerző - aki a Kaliforniai Egyetem professzoraként oktat várostervezést már korábbi munkájába beépítette a térbeli igazságosság elméletét (Soja 2000), de ennek részletesebb kifejtése egészen idáig váratott magára. A Seeking Spatial Justice kulcsgondolata a tér- és társadalomtudományok eredményei közötti szoros kapcsolat feltárása, a társadalom és az azt magában foglaló tér közötti dialektikus viszony leírása. Ez utóbbi már Marxnál is központi szerepet játszott, ebben a vonatkozásban viszont egészen az ezredfordulóig nem alkalmazták - annak ellenére, hogy maga Soja már mintegy három évtizede megfogalmazta a térbelitársadalmi dialektika fogalmát (Soja 1980). A mű elején megfogalmazott tudománytörténeti előrelépés szerint a földrajz elméleti tudománnyá válását - tehát a többi társadalomtudomány felől érkező gondolati rendszerek földrajzba történő beépülését - egy ellentétes irányú folyamat, a földrajzi térszemlélet széles körủ adaptálása követte. Ez az úgynevezett térbeli fordulat (spatial turn) új, kritikai szemléletet jelent a korábban „tértelen” társadalomtudományok számára. Soja azonban hangsúlyozza, hogy nála a történelmi-társadalmi szemlélet és a térben való meghatározottság gondolata egyenrangú, a két megközelítés valójában elválaszthatatlan egymástól, így ugyanazon társadalmi jelenségekről csak mindkét szempont együttes alkalmazásával nyerhetünk teljes képet. Az egyik esetében bekövetkező változások alakítják, formálják a másikat is. Mégis, ha alaposabban megvizsgáljuk, akkor rájöhetünk, hogy Soja szemléletmódja jellegzetesen földrajzi: könyve nagy részében társadalmi folyamatokat elemez kritikai geográfiai megközelítésben.

E térbeli-társadalmi dialektika szemléletmódjának alkalmazása az igazságosság esetében azt jelenti, hogy a társadalmak létezésétől kezdődően folyamatosan és spontán módon igazságtalan helyzetek jönnek létre, amelyek a földrajzi 
tér használatában is kifejezésre jutnak. A tér tudatos felosztása a használói között ugyanakkor szintén eredményezhet társadalmi szempontból igazságtalan helyzeteket. A szerző szerint e helyzetek sokszor újratermelődnek, amiben leginkább a hatalmi szempontból domináns társadalmi csoportok akarata jut érvényre.

A szerző ezt a gondolatmenetet követi végig művében, amely - az előszót és a bevezetőt nem számítva - tartalmilag két nagyobb egységre tagolódik. Az első az elméleti megállapítások szisztematikus kifejtése, míg a második egy Los Angeles-i esettanulmányon keresztül példázza a térbeli igazságosság problematikájának összetettségét. A kötet induktív logikával építkezik, és gondolatainak szintézisére Soja az elméleti rész végén, illetve a munkát záró globális szintü kitekintésben kerít sort.

Az első egység tehát a lényegesebb fogalmak körbejárásával indít. A szerző az olvasó nagy örömére - különös hangsúlyt fektet annak tisztázására, hogy mit is ért térbeliségen és igazságosságon. A térbeliség vonatkozásában az az új típusú térfelfogás a meghatározó, amely már nemcsak a tér materiális jellemzőit veszi számba, hanem jelentősen elvonatkoztat a fizikális valóságtól. Így válik értelmezhetővé a társadalmi tér fogalma mint komplex társadalmi „termék”, a társadalom által megélt és tudatosan formált tér, ahol a tér nem pusztán események „kerete”, hanem befolyásoló erők, tényezők komplex rendszere. Ez valójában nem új keletü gondolat, hiszen Lefebvre-nél vagy a humanisztikus geográfiában is olvashattunk erről, és mára széles körben elfogadott megközelítésről van szó. Ami mégis más a korábbi munkákhoz képest, az az, hogy Soja nem fogadja el a társadalmi szféra felsőbbrendűségét, az ebből fakadó determinizmust, hanem a társadalom és a tér között fennálló dialektikus kapcsolatrendszer mellett foglal állást.

Az igazságosság - mint a címadó fogalom másik összetevője - hasonló súllyal jelenik meg a fogalmak ismertetésénél. A Soja által adaptált igazságkoncepció messze túlmegy a jogi értelemben vett igazságfelfogáson. Kiindulópontjai a John Rawls-tól átvett méltányosság alapú igazságosság', valamint az igazságos társadalom felvilágosult ismérvei, mint például szabadság, függetlenség, egyenlőség, demokrácia, civil jogok. A szerző ugyanakkor Rawls-hoz képest dinamikusabb álláspontra helyezkedik, konkrét társadalmi helyzetekből, mozgalmakból fakadó feszültségekre koncentrál, és azokra a törekvésekre, amelyek egy csoport érdekeit hivatottak érvényre juttatni. Soja szerint napjaink globalizált világában, az információs kapitalizmus korszakában jóval összetettebbek a társadalmi konfliktusok, érdekcsoportok, amelyek ráadásul különböző földrajzi léptéken jelentkezhetnek. Emiatt válik fontossá a politikai célok összefonódása, a koalíciókeresés, ahol a reális célkitűzés nem a szembenálló társadalmi csoportok közötti nagyobb egyenlöség, hanem egy igazságosabb helyzet keresése lehet. Ez az értelmezés tekinthető a marxi nézetek meghaladásának is, hiszen a korábbi „kétarcú” ellentétek, mint munkások-tőkések, feketék-fehérek, melegek-nem melegek szembenállása már túlságosan leegyszerűsítené a társadalmi konfliktusokat. A szerző - kapcsolódva ezzel a posztstrukturalista gondolkodáshoz és a földrajz kulturális fordulatához óva inti olvasóját a kategóriákban való gondolkodástól. 
Soja művének kétségkívül nagy érdeme, hogy állításait már a könyv elméleti részében számos példával illusztrálja. Először a térhasználatban megmutatkozó igazságtalan társadalmi viszonyok bemutatására törekszik különböző földrajzi léptékeken. A lényeg azonban nem a lépték kérdése, hanem a térbelitársadalmi szempontból igazságtalan helyzet kialakulásának mechanizmusa. A szerző megkülönböztet külső hatásra bekövetkező (exogén) igazságtalansági viszonyokat, ahol valamilyen domináns politikai erő, kulturális elnyomás hatására szerveződik a térhez való hozzájutás igazságtalanul. Példaképp említi többek között Párizs jelentős számban bevándorlók, idegen ajkúak lakta külső városrészeit és a közelmúltban ott kitört zavargásokat, a korábbi gyarmatok felszabadulás után továbbra is fennálló függőségét, a gerrymanderinget, az apartheid politikáját Dél-Afrikában, illetve a városi közterekhez való hozzáférést a kapitalista gazdaságokban. Mindegyiknél megfigyelhető, hogy a földrajzi tér használatát és megélését korlátozzák, befolyásolják az elnyomott csoportok kárára.

Az igazságtalan viszonyok másik csoportját a belső (endogén) társadalmi mechanizmusok miatt kialakuló helyzetek adják. Itt a hangsúly a helyi szint szerepén, az autonóm döntéshozatalból fakadó kiegyensúlyozatlan térhasználaton van. Ilyennek tekinthetők például a társadalmi szegregáció különböző típusai, illetve a környezeti szempontból igazságtalan helyzetek. Soja külön példaként említi a közszolgáltatások (pl. lakhatási, oktatási, egészségügyi szolgáltatások) városokra jellemző egyenlőtlen eloszlását, ami erősen tagolja a városok belső tereit. Ezt sokáig pusztán „szükséges rosszként”, a városi léttel együtt járó „kellemetlenségként" fogták fel. Soja itt azonban - Harvey-t idézve - az igazságtalanság urbanizációjáról beszél, vagyis az igazságtalanság társadalmi beágyazottságáról, ami mögött különböző érdekcsoportok tevékenysége és politikai döntések sora húzódik meg. Ezekkel szemben mutatkozik meg a térért folyó és magában a térben lezajló küzdelem. A professzor szinte politikai programként fogalmazza meg, hogy mennyire szükséges és fontos az igazságosabb társadalmi viszonyok érdekében történő összehangolt fellépés. A szerző gondolatai itt szorosan kapcsolódnak a - többek közt Lefebvre és Harvey nevével fémjelzett "right to the city” mozgalomhoz², amely az urbánus társadalmi problémákról alkotott elméleteket politikai aktivitással, a beavatkozási és cselekvési lehetőségek feltárásával törekszik érvényre juttatni.

A szerző ezt követően a különböző földrajzi léptékek szempontjából is bemutatja az előbb felvázolt helyzeteket, amelyekre a globális szinten megmutatkozó igazságtalanságoktól egészen a regionális szinttel bezárólag hoz példákat. Ebben a megközelítésben a területi különbségek kérdése, fejlettség és fejletlenség szembenállása lényeges. A professzor rávilágít, hogy a kiegyensúlyozatlan területi viszonyok jórészt a kilencvenes évek közepéig széles körben alkalmazott versenyorientált regionális politikának „,köszönhetők”. Ezt váltotta fel napjainkra az „új regionalizmus”, amely már a szociális-jóléti eredmények megőrzését, az igazságosság regionális erősítését helyezi előtérbe. Mindez természetesen tovább erősíti a térfolyamatokba történő tudatos beavatkozás fontosságát. 
Miben is áll tehát Soja térbeliigazságosság-elmélete? A mü gerincét - és egyben az elméleti fejtegetések lezárását - adó konklúzió az előbb ismertetett fogalmak szintézisét adja. A szerző példásan módszeres logikát követve építi fel saját térbeliigazságosság-értelmezését, amelynek alapvetése a társadalmi fejlődés - történelmi múlt - térhasználat hármas dialektusa, valamint az ebből következő állítás, miszerint a területileg egyenlőtlen fejlődés szükségszerű velejárója minden társadalmi folyamatnak. Ezek a földrajzi egyenlőtlenségek egyúttal társadalmilag igazságtalan helyzeteket eredményeznek. A térbeli igazságosság fogalma tehát e két jelenség összekapcsolódását takarja.

A professzor gondolata - miszerint a térbeli igazságosság kérdése tipikusan a város kontextusában jelentkezik - alátámasztja a történelmi fejlődéssel fennálló szoros kapcsolatot. Mint tudjuk, az ókori társadalmak is igen fejlett városi kultúrával rendelkeztek. Az akkori városok tereinek tagolódása már erősen tükrözte az igazságtalan társadalmi viszonyokat, a despotikus, elnyomó hatalom dominanciáját, még a bizonyos társadalmi rétegek esetében demokratikusnak mondott görög poliszok esetében is. Az újkorban lezajló urbanizáció fellendülésével további markánsan igazságtalan viszonyok keletkeztek (például az ipari forradalom nagy iparvárosaiban), napjainkra pedig - a felgyorsult városfejlődés, a megalopoliszok és a hiperurbanizáció korszakában - már rendkívül bonyolult ezek felderítése. Soja tehát elfogadja azt a lényegében marxi gyökerü gondolatot, hogy a térbeli igazságosság történelmi vonatkozással is bír. Lényeges hangsúlyozni, hogy a térbeli igazságosság mindezek alapján értelmezhető egyrészt pusztán a társadalmi tényezők és a térhasználat viszonylagos összhangjaként, mintegy a jólétért és a területi egyenlőségért folytatott hosszas küzdelem célkitűzéseként. Másrészt viszont - a mai kor embere számára - felfogható a lefebvre-i radikálisabb politikai megközelítés mentén is mint a különböző társadalmi csoportok elnyomó erőkkel szembeni összehangolt, aktív fellépését megkövetelő idea. Soja választása ez utóbbira esik, amit a továbbiakban a két kiemelt kutató, Harvey és Lefebvre gondolatainak egyéni interpretációjával is alátámaszt.

A könyv valószínűleg befejezetlen maradt volna, ha a teória felállítása után a szerző nem törekszik az igazságosság térbeliségének konkrét példával történő alátámasztására, az elméletben ismertetett kategóriák valós szituációban történő értelmezésére. Ez a kötet második egységében bemutatott esettanulmányban ölt testet, amely - a professzor véleménye szerint - történelmi fordulópont a térbeli igazságosságért folytatott küzdelemben.

1996-ban precedens értékü ítélet született a Los Angeles-i bíróságon, amelyben kötelezték a városi közlekedési társaságot, hogy minden tömegközlekedésre rászoruló városlakó számára tegye igazságosan hozzáférhetővé szolgáltatásait. Az eset akkoriban különösen nagy visszhangot keltett, hiszen korábban nem fordult elő, hogy egy urbánus teret dominánsan alakító szereplőt igazságosabb, területileg kiegyenlítettebb szolgáltatások biztosítására szólítsanak fel. Soja hosszú oldalakon taglalja az ezt megelőző társadalmi mozgalmak okait és az 
érdekszövetségek kialakulását. Az 1960-as évektől folyamatosan erősödő munkások, szakszervezetek, bevándorlók és más alacsony státusú rétegek koalíciói szinte iskolapéldáját adják a sojai értelemben vett térbeli igazságosságért folytatott küzdelemnek, ami az érintett csoportok közös, aktív fellépésén nyugszik. A Los Angeles-i példa esetében kiemelt a hátrányosan érintett csoportok szegregálódása, lakóhelyük és érvényesülési lehetőségeik negligálása. Küzdelmük a jobb közlekedési viszonyokért, mintegy a térhez való kiegyenlítettebb hozzáférésért markáns területi vonatkozással rendelkezik. Tudatos fellépésük lényeges momentuma volt konkrét területi célok és stratégiák megfogalmazása, és ehhez kapcsolódóan várostervezés- és geográfusszakos egyetemi hallgatók, szakemberek bevonása a térért folytatott küzdelem mintegy szakmai „megalapozásába”. Fontos kiemelni, hogy ez a mozgalom az évtizedek folyamán túlnőtte Los Angelest, és összekapcsolódott más városokban zajló hasonló küzdelmekkel.

A könyv végén olvasható globális szintű kitekintés Soja művének egyfajta konklúziója. A szerző itt röviden ír arról, mi változott a világban az ezredforduló után, és mi várható a térbeli igazság keresésétől napjainkban. A professzor különös jelentőséget tulajdonít a 2001. szeptember 11-i terrortámadásoknak és a 2008-ban kezdődött gazdasági világválságnak. Ezek a globális politikai és gazdasági fenyegetettség erősödő jelenlétét mutatják, ami természetesen hatással van a helyi társadalmi szerveződésekre. A legfontosabb változás a térbeli igazságosságért folytatott küzdelem kiszélesedése és nemzetköziesedése, amely a „rigth to the city" mozgalmak szövetségének megszületésében öltött testet 2007-ben. Bár ez még egészen friss kezdeményezés, sikerült világos és konkrét célokat megfogalmazni, többek között a városi közösségek konfliktusainak felderítését, a problémás területekre fókuszáló stratégiák és akcióprogramok meghirdetését, városok és régiók közötti tapasztalat- és információcserét, illetve a szervezet működésének bázisát jelentő regionális szervezetek létrehozását. A már globális szinten gondolkozó szervezet ténylegesen globális kihívásokkal néz szembe, amit jól példáznak az elmúlt évek Wal-Mart botrányai, ahol a helyi közösségekkel szembeni visszaélések már nemcsak egy területen koncentráltan jelentek meg, hanem az áruházlánc több helyszínén is.

Soja összességében arra a következtetésre jut, hogy a globalizált világ kialakulásával a városi terek használata mögött húzódó társadalmi konfliktusok egyre inkább elmélyülnek, az urbanizáció fokozódása folyamatosan termeli a térbeli igazságtalanságokat. A sokszor méltatlan helyzetek felszámolásáért azonban lehet és kell is tenni, ami viszont csak politikai síkra terelve, összehangoltan, a konfliktusok által érintett összes szereplővel karöltve lehet sikeres. A politikai szövetségek építése és a tapasztalatok nemzetközi megosztása alapvető fontosságú. Ehhez ugyanakkor nélkülözhetetlen a kritikai földrajzi megközelítés, hiszen a geográfia segítségével érthetők meg az eltérő földrajzi léptéken tapasztalható térbeli igazságtalanságok összefüggései. Ez talán a kaliforniai professzor művének legfontosabb gondolata: innentől kezdve tér, történelem és társadalom nem elválasztható fogalmak, igazságtalannak vélt viszonyok ellen pedig csak úgy lehet 


\section{Móricz Ádám}

küzdeni, ha azok térbeliségével is számot vetnek a politikai mozgalmak befolyásos személyiségei.

Ajánlható e kötet mindazoknak, akik szakemberként foglalkoznak társadalmi folyamatok megítélésével. Így a geográfusok, urbanisták mellett például a szociológusoknak, történészeknek is, akik számára a területiség kérdése eddig esetleg idegennek, újszerűnek hathatott. Ha valaki idegenkedik is Soja gondolataitól, mondván, hogy azok túlzott reményeket fogalmaznak meg a progresszív társadalmi változásokkal kapcsolatban, annak bizakodásra adhat okot, hogy a szerző a közelmúltbeli pozitív kezdeményezésekre hivatkozva optimista végkicsengéssel zárja művét. Az eddig elért eredményekre hivatkozik, amellett kellő nyitottságra buzdítja a társadalmi mozgalmak minden érintett szereplőjét. Bennünk, olvasókban mégis felmerül a kérdés: lépést tud-e tartani az igazságos társadalmi viszonyok védelme a hatalmi rendszerek egyre fokozódó globális térnyerésével?

\section{Jegyzetek}

1 Az igazságosság elveiben való előzetes megegyezés, ami így hipotetikusan független a társadalmi pozícióból fakadó egyéni érdekektől (Rawls 1997).

2 A magyar földrajzi-szociológiai szaknyelvben és az aktivista szférában „A város mindenkié” néven ismert mozgalom a különböző marginális helyzetü társadalmi csoportok lokális döntési folyamatokba való beleszólásra törekvését jelöli. Harvey a spontán társadalmi szerveződéseket és az urbanizáció egyes jelenségeit is ilyen törekvések megnyilvánulásaként fogja fel. Lefebvre-nél és Sojánál a városhoz való jog már buzdító jelszó a hátrányos helyzetű csoportok szélesebb koalíciójának megteremtésére.

\section{Irodalom}

Davies, B. (1968): Social Needs and Resources in Local Services: A Study of Variations in Provision of Social Services between Local Authority Areas. Joseph Rowntree, London

Dikec, M. (2001): "Justice and the Spatial Imagiation". Environment and Planning A, 33. évf., $1785-1805$.

Harvey, D. (1973): Social Justice and the City. Edward Arnold, London

Lefebvre, H. (1991): The Production of Space. Wiley-Blackwell, Oxford

Pirie, G. H. (1983): „On Spatial Justice”. Environment and Planning A, 15. évf., 465-473.

Rawls, J. (1997): Az igazságosság elmélete. Osiris, Budapest

Soja, E. W. (2000): Socio spatial dialectic. Annals of the Association of American Geographers, 2., 207-225.

Soja, E. W. (2000): Postmetropolis: Critical Studies of Cities and Regions. Basil Blackwell, Oxford 